\title{
Oxisol physical quality with application of landfill leachate
}

\section{Qualidade física de Latossolo com aplicação de lixiviado de aterro sanitário}

\author{
Jean Carlo Santos de Oliveira ${ }^{1}$; José Francirlei de Oliveira²; Alex Figueiredo후 \\ Graziela Moraes de Cesare Barbosa ${ }^{3}$; João Tavares Filho**
}

\begin{abstract}
The organic carbon present in the landfill leachate (LL) can improve the physical quality of the soil when applied in agricultural areas, minimizing the problem of disposal of this waste. The objective of this work was to evaluate the effect of the application of different doses of LL on the physical quality of the LATOSSOLO VERMELHO (Oxisol) after five years of applications. The treatment consisted of applications of LL in doses of 32, 65, 98 and $130 \mathrm{~m}^{3} \mathrm{ha}^{-1} \mathrm{crop}^{-1}$ and the treatment that receives mineral fertilizer. The physical quality of the soil was evaluated in soil samples collected in the layers $0.00-0.10$ and $0.10-0.20 \mathrm{~m}$, through the analysis of stability and diameter of the aggregates, soil density, total aeration capacity, field capacity and available water content. After five years of application of LL, at doses of 65,98 and $130 \mathrm{~m}^{3} \mathrm{ha}^{-1} \mathrm{crop}^{-1}$ have promoted a linear increase of the aggregates with diameter greater than $2.00 \mathrm{~mm}$, of the weighted average and geometric diameters and of the soil density, with a consequent reduction of the ratio between macro and micropores and the aeration capacity of the layers $0.00-0.10$ and $0.10-0.20 \mathrm{~m}$. After five years of these applications, the soils that received the dose of 32 $\mathrm{m}^{3} \mathrm{ha}^{-1} \mathrm{crop}^{-1}$ presented the best physical quality in relation to the other doses, since this dose did not promote an increase of the aggregates larger than $2 \mathrm{~mm}$ in the superficial layer $(0.00-0.10 \mathrm{~m})$ and was the dose with lower effect in the reduction of aeration of the soil, in relation to the others $(65,98$ and $\left.130 \mathrm{~m}^{3} \mathrm{ha}^{-1} \mathrm{crop}^{-1}\right)$ in the layers $0.00-0.10$ and $0.10-0.20 \mathrm{~m}$.
\end{abstract}

Key words: Soil management. Soil porosity. Soil structure.

\section{Resumo}

O carbono orgânico presente no lixiviado de aterro sanitário (LAS) pode melhorar a qualidade física do solo quando aplicado em áreas agrícolas, minimizando o problema de descarte desse dejeto. O objetivo do trabalho foi avaliar o efeito da aplicação de diferentes doses de LAS sobre a qualidade física de um LATOSSOLO VERMELHO Distroférrico após cinco anos de aplicações. Os tratamentos consistiram de aplicações de LAS nas doses de 32, 65, 98 e $130 \mathrm{~m}^{3} \mathrm{ha}^{-1}$ safra $^{-1}$ e um tratamento que recebe fertilizante mineral. A qualidade física do solo foi avaliada em amostras de solo coletadas nas camadas 0,00-0,10 e 0,10-0,20 m, por meio da análise da estabilidade e diâmetro dos agregados, densidade do solo, capacidade de aeração total, capacidade de campo e teor de água disponível. Após cinco anos de aplicações de LAS, nas doses de 65, 98 e $130 \mathrm{~m}^{3}$ ha $^{-1}$ safra $^{-1}$ promoveram aumento linear dos agregados com diâmetro maior que $2,00 \mathrm{~mm}$, dos diâmetros médio ponderado e geométrico e da densidade do solo, com consequente redução da razão entre macro e microporos e da capacidade de aeração das camadas $0,00-0,10$ e 0,10-0,20 m. Após cinco anos de aplicações de LAS, os solos que receberam a dose

\footnotetext{
${ }^{1}$ Discentes, Curso de Doutorado do Programa de Pós-Graduação em Agronomia, Universidade Estadual de Londrina, UEL, Londrina, PR, Brasil. E-mail: jeancarlo_agro@hotmail.com; alexkdn@hotmail.com

2 Eng $^{\mathrm{o}} \mathrm{Agr}^{\circ}$, Dr., Instituto Agronômico do Paraná, IAPAR, Londrina, PR, Brasil. E-mail: jfoliveira79@gmail.com

${ }^{3}$ Pesquisadora Dr ${ }^{\mathrm{a}}$, IAPAR, Área de Física do Solo, Londrina, PR, Brasil. E-mail: graziela_barbosa@iapar.br

${ }^{4}$ Prof. Dr., Departamento de Agronomia, UEL, Londrina, PR, Brasil. Bolsista CNPQ 1D. E-mail: tavares@uel.br

* Author for correspondence
} 
de $32 \mathrm{~m}^{3} \mathrm{ha}^{-1}$ safra $^{-1}$ apresentaram a melhor qualidade física em relação às demais doses, pois, essa dose não promoveu aumento dos agregados maiores que $2 \mathrm{~mm}$ na camada superficial $(0,00-0,10 \mathrm{~m})$ e foi a dose com menor influência na redução da aeração do solo, em relação às demais $\left(65,98\right.$ e $130 \mathrm{~m}^{3} \mathrm{ha}^{-1}$ safra $^{-1}$ ) nas camadas $0,00-0,10$ e $0,10-0,20 \mathrm{~m}$.

Palavras-chave: Manejo do solo. Porosidade do solo. Estrutura do solo.

\section{Introduction}

The population of Latin America produces $13 \%$ of the global total amount of municipal solid waste (MSW) (more than 100 million tons), with an average daily production of $1.0 \mathrm{~kg}$ of MSW per inhabitant, while in developed countries, such as the North America, the average daily production is $1.9 \mathrm{~kg}$ of MSW per inhabitant (HOORNWEG; BHADA-TATA, 2012). These residues may be regarded as one of the greatest environmental problems and public health of cities, mainly due to inadequate management (SILVA et al., 2012; REIS et al., 2015).

One of the ways to allocate these residues is the deposit in landfills, the construction of this deposit requires a prior study of the environmental impact in the region and cares such as the deployment of drainage systems, which will guide the landfill leachate (LL) for a pond treatment and stored in tanks commonly waterproofed with clay and double layer of geomembrane of HDPE, to prevent percolation of LL to the subsoil (ABNT, 1992; MARTINS et al., 2010).

The LL is produced by the decomposition of organic matter contained in the SMW, it has a black color and bad smell and its final destination after storage in these tanks is an environmental problem, whose solution must be studied.

Whereas the production of LL is derived from the decomposition of organic material, the application of this residue in the soil has been studied as a way to improve their chemical attributes and retrieve the degradation processes. Thus, the controlled application in agricultural soils can be an alternative for final disposal, after a period of storage in tanks, and even promote the cycling of nutrients and improving soil fertility and soil structure (MANGIERI; TAVARES FILHO, 2015).

The soil structure resulting from the formation and stabilization of aggregates, plays an important role on the processes of infiltration and water retention, porosity, aeration and resistance to root penetration, whose proportions of change and resilience are dependent on the management on which the soil is subject to. Therefore, indicators of soil quality such as the total porosity, macro and microporosity, total aeration, field capacity, permanent wilting point, diameter, distribution and stability of aggregates, which are directly related to its structure and porosity have been shown to be susceptible to the changes promoted by management (MORAES et al., 2016; CHERUBIN et al., 2015; MAZURANA et al., 2011).

When an organic material is applied in the soil, it is expected that there will be a reduction of soil density and increased porosity, aeration and water retention capacity, with a consequent increase of availability for the plants, however, the results are still controversial in relation to these benefits. Oliveira et al. (2015) observed that the applications of organic material, by means of swine manure, did not influence the soil structure and Barbosa et al. (2015) observed in experiment of eight years duration in a Red Latosol (Oxisol), that the aviary manure improves the soil structure in the first 15 days after the application. As for the LL, the information is commonly directed to the works that evaluate the phyto-extraction of heavy metals through the development of plants and processes of sorption and desorption in clays, in areas of landfill, already infected, as in Coelho et al. (2016), Salam et al. (2016) and Rong et al. (2017). 
When the LL is applied to the soil as an organic fertilizer, there is an increase in the force of plants (AGOSTINI et al., 2007) and a positive relationship of the increase of LL doses in the soil (from 30 to $120 \mathrm{~m}^{3} \mathrm{ha}^{-1}$ ) with maize grain yield and biomass production of oats, especially by increasing the efficiency of use of $\mathrm{N}$ and $\mathrm{K}$ by the plant, when applied in the form of LL (PANCHONI et al., 2016; KUWANO et al., 2017).

As an organic fertilizer, it is known that the amount of nutrients present in them is beneficial to the chemical fertility of the soil (GALKO, 2015; HAARSTAD et al., 2016), with a stimulus of microbiological activity and an increase of the the efficiency of use of nitrogen (PANCHONI et al., 2016; KUWANO et al., 2017). However, the assessment of the effects of the application of LL on indicators of soil physical quality (structure and porosity) are limited, especially in experiments of long duration.

The hypothesis of this study is that the application of LL as an organic fertilizer improves the physical quality of a Red Latosol (Oxisol). The objective of this study was to evaluate the effect of different doses of LL on the physical quality of an Oxisol, after five years of applications.

\section{Material and Methods}

Area of study and experiment

The experiment was conducted at the Experimental Station of the Instituto Agronômico

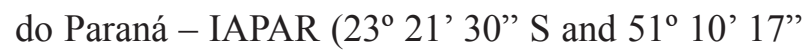
$\mathrm{W})$. The average altitude of the area is $570 \mathrm{~m}$ and the average annual rainfall is $1,616 \mathrm{~mm}$. The climate is of type Cfa, humid subtropical with an average annual temperature of $22.5^{\circ} \mathrm{C}$ (ALVAREZ et al., 2013). The soil is a typic LATOSSOLO VERMELHO (Oxisol) very clayey, originating from basalt, with $840 \mathrm{~g} \mathrm{~kg}^{-1}$ of clay, $130 \mathrm{~g} \mathrm{~kg}^{-1}$ of silt and $30 \mathrm{~g} \mathrm{~kg}^{-1}$ of sand, with high levels of iron oxides $\left(>180 \mathrm{~g} \mathrm{~kg}^{-}\right.$ $\left.{ }^{1}\right)$, well drained, little differentiation between the horizons, strong microgranular structure and well developed, developed under mild relief boxes with approximately $2 \%$ of slope.

The area of the experiment was previously cultivated with annual crops, soybean or corn in spring-summer and wheat or oats in the period of autumn-winter, in no-tillage system until the year 2007, it should be emphasized that the area never received application of some urban or agroindustrial residue.

From the winter harvest (black oat) of 2008, the experiment was installed in a randomized block design with five treatments (LL doses) and four replications, in plots of $48 \mathrm{~m}^{2}$. The treatments were: control (0), with no applications of LL and application of $90 \mathrm{~kg}$ ha- 1 of $\mathrm{N}$ season ${ }^{-1}$ (in the form of urea) and applications of 32, 65, 98 and $130 \mathrm{~m}^{3}$ ha $^{-1}$ season $^{-1}$ of LL, equivalent to $30,60,90$ and 120 $\mathrm{kg} \mathrm{ha}^{-1}$ season $^{-1}$ of $\mathrm{N}$ total. In the first year (2008) there were three applications (28 July, August 12 and October 28) and further details of these applications can be found in Santos et al. (2013). For practical reasons, the $\mathrm{N}$ doses were kept the same throughout the years. From 2009 until July 2013 (the date of sample collection for this study) the maize crops were used in the summer and oats in the winter and both yearly applications were always performed three to four days before the sowing of these crops. The applications were performed with the aid of watering cans, in surface and without incorporation.

The oat was planted with $17 \mathrm{~cm}$ between rows and 20 seeds per linear meter and the corn with $80 \mathrm{~cm}$ between rows and five seeds per meter. The spraying of pesticides and herbicides, and the crops were conducted in a mechanical fashion.

The macronutrients of treatment 0 were placed in the seeding and in treatments that received different doses of LL, cultures did not receive any type of chemical fertilizer, considering that they were already present in them.

The LL used, since the implementation of the experiment was collected on the Sanitary Landfill 
of Household Solid Waste of Londrina - PR (51 ${ }^{\circ} 06^{\prime}$ S, $23^{\circ} 20^{\prime}$ S). Further details of the management history and applications can be found in Santos et al. (2013) e Panchoni et al. (2016). The mean values of the chemical properties of the leachate used in applications are presented in table 1.

Table 1. Average values of the chemical properties of the landfill leachate used for applications during the experiment between 2008 and 2013.

\begin{tabular}{lc}
\hline \multicolumn{1}{c}{ Properties } & Average values \\
\hline $\mathrm{C}$ total $\left(\mathrm{g} \mathrm{L}^{-1}\right)$ & 0.130 \\
$\mathrm{~N}$ total $\left(\mathrm{g} \mathrm{L}^{-1}\right)$ & 0.875 \\
Electrical conductivity (dS m-1) & 10.16 \\
$\mathrm{pH}$ & 8.26 \\
Alkalinity (mg CaCO3 L-1) & 4736 \\
Total solids & 6145 \\
$\mathrm{P}$ total (mg L-1) & 4.90 \\
$\mathrm{Ca}^{2+}\left(\mathrm{mg} \mathrm{L}^{-1}\right)$ & 68 \\
$\mathrm{Mg}^{2+}\left(\mathrm{mg} \mathrm{L}^{-1}\right)$ & 114 \\
$\mathrm{SO}_{4}^{-2}\left(\mathrm{mg} \mathrm{L}^{-1}\right)$ & 39 \\
$\mathrm{Cl}^{-}\left(\mathrm{mg} \mathrm{L}^{-1}\right)$ & 1981 \\
$\mathrm{Na}^{+}\left(\mathrm{mg} \mathrm{L}^{-1}\right)$ & 866 \\
$\mathrm{~K}^{+}\left(\mathrm{mg} \mathrm{L}^{-1}\right)$ & 932 \\
\hline
\end{tabular}

\section{Procedures for sampling and analysis}

Samples were taken from soil samples in layers of 0.00-0.10 and 0.10-0.20 m with deformed structure and undisturbed soil. The samples were collected after harvesting the crop of oats in the season 2013, in rows, after 12 applications of different doses of LL in six years of experiment. In each layer, the samplings were carried out in triplicate, in between the culture of oats, the deformed samples were grouped together and formed a composite sample per plot of the experiment.

For the analysis of stability and distribution of classes of aggregates, the samples were collected with the aid of a cutting shovel and, still in the field, were sieved in a mesh sieve of $19 \mathrm{~mm}$, with the goal of establishing a maximum diameter for clusters (CASTRO FILHO et al., 1998). The determinations of diameter classes were conducted by means of wet sieving (for 15 minutes), as proposed by Yoder (1936) and adapted by Castro Filho et al. (1998), using sieves with mesh size of $8,4,2,1,0.5$ and $0.25 \mathrm{~mm}$. The soil retained in each sieve was dried in an oven at $105^{\circ} \mathrm{C}$ for $24 \mathrm{~h}$, and then weighed. The class of aggregate smaller than $0.25 \mathrm{~mm}$ was calculated by subtracting the sum of the total weight of the dried sample of other classes. The mean values obtained for each class were used for the calculation of the mean weight diameter (MWD), geometric mean diameter (GMD) and aggregate stability index (ASI). The diameters were obtained by means of the following equations:

Mean weight diameter:

$$
M W D=\sum_{i=1}^{n}(x i . w i)
$$

Where:

$\mathrm{Wi}=$ proportion of each class in the total;

$\mathrm{Xi}=$ average diameter of classes $(\mathrm{mm})$;

Geometric mean diameter (GMD):

$$
G M D=E X P \frac{\sum_{I=1}^{N} w p \cdot \log x i}{\sum_{I=1}^{N} w i}
$$


Where:

$\mathrm{Wp}=$ weight of households in each class $(\mathrm{g})$;

$\mathrm{Wi}=$ proportion of each class in relation to the total.

Aggregate Stability Index (ASI):

$$
A S I=\left(\frac{\text { dry sample weight }-w p 25-\text { sand }}{\text { dry sample weight }- \text { sand }}\right) \cdot 100
$$

Where:

$\mathrm{Wp} 25=$ dry weight of aggregates of class $<0.25$ $\mathrm{mm}$.

The samples with undisturbed soil structure were collected in cylinders of $5 \mathrm{~cm}$ in diameter and 5.06 $\mathrm{cm}$ in height. For the determination of the indicators of soil porosity, the samples were subjected to the tension of -0.006 and $-0.01 \mathrm{MPa}$ in a bureau of tension and the stresses of $-0,0333 ;-0.1 ;-0.3 ;-0.5$ and $-1.5 \mathrm{MPa}$ in extractors of Richards with porous baffle (KLUTE, 1986; DANE; HOPMANS, 2002), obtaining the weight of water retained in each applied voltage. From these results we calculated the macroporosity $\left(0-10 \mathrm{kPa}, \mathrm{m}^{3} \mathrm{~m}^{-3}\right)$, microporosity ($\left.10 \mathrm{kPa}, \mathrm{m}^{3} \mathrm{~m}^{-3}\right)$, total aeration $\left(0-100 \mathrm{KPa}, \mathrm{m}^{3} \mathrm{~m}^{-3}\right)$, the field capacity $\left(-100 \mathrm{kPa}, \mathrm{m}^{3} \mathrm{~m}^{-3}\right)$ and the water content available $\left(-1000 \mathrm{kPa}, \mathrm{m}^{3} \mathrm{~m}^{-3}\right)$.

The samples with undisturbed soil structure were also used for the determination of soil density (Ds), whereas the ratio between the mass of dry soil at $105^{\circ} \mathrm{C}$ and the volume of the ring $\left(100 \mathrm{~cm}^{3}\right)$.

In the samples with deformed structure the content of organic carbon was determined (DONAGEMA et al., 2011).

\section{Statistical analyzes}

The data were submitted to the test of normality (Shapiro-Wilk), homogeneity of variance (Levene's test) and then to the ANOVA. As the differences between the treatments were noted, they were presented using the standard error, which indicates the standard error of the difference between the averages and, when the lines do not meet, the difference is significant at a $5 \%$ probability. The analyses of linear or square regression were used to observe the relations of different doses of LL with the physical properties and organic carbon content of the soil.

\section{Results}

\section{The superficial layer $(0.00-0.10 \mathrm{~m})$ of the soil}

In the surface soil layer $(0.00-0.10 \mathrm{~m})$, the applications of 65,98 and $130 \mathrm{~m}^{3} \mathrm{ha}^{-1}$ season $^{-1}$ of LL increased the stability index and the clusters with a diameter greater than $2.00 \mathrm{~mm}$, in relation to the treatment 0 and $32 \mathrm{~m}^{3}$ ha $^{-1}$ season $^{-1}$ (Figures 1a and $b$ ). In the same way, the applications of 65,98 and $130 \mathrm{~m}^{3} \mathrm{ha}^{-1}$ season $^{-1}$ of LL increased the GMD and MWD of aggregates in the soil, in relation to the lowest dose of LAS ( $32 \mathrm{~m}^{3}$ ha $^{-1}$ season $\left.^{-1}\right)$ or absence of application (treatment 0 ), with an increase of $0.2 \mathrm{~mm}$ diameters for each cubic meter of LL applied (Figures 2a, c). As a consequence of the increase in the mean diameter of the aggregates, the applications also led to an increase of the soil density in the following order $0<32<65=98=130$, with an increase of $0.019 \mathrm{Mg} \mathrm{m}-3$ to each cubic meter of LL applied. (Figure 3a). 
Figure 1. Percentage of the sum of the aggregates larger than $2.00 \mathrm{~mm}(\Sigma$ aggregates $>2.00 \mathrm{~mm})$ and the index of stability of aggregates (ASI) of layers $0.00-0.10(a, b)$ and $0.10-0.20 \mathrm{~m} \mathrm{(c,d)} \mathrm{of} \mathrm{the} \mathrm{soil} \mathrm{after} \mathrm{six} \mathrm{years} \mathrm{of} \mathrm{applications}$ of landfill leachate (LL) at doses 0, 32, 65, 98 and $130 \mathrm{~m}^{3} \mathrm{ha}^{-1}$ season $^{-1}$ The lines indicate the standard error of the difference between the averages and when they do not match they indicate that the difference is significant at a $5 \%$ probability rate.

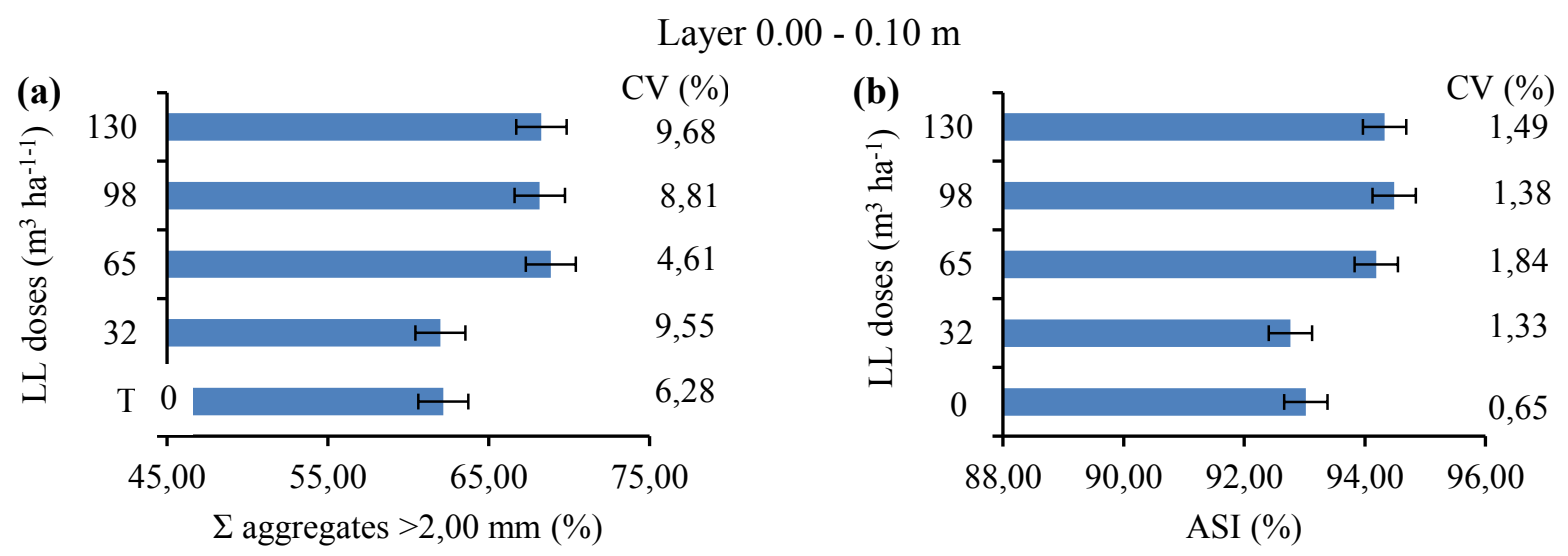

Layer $0.10-0.20 \mathrm{~m}$

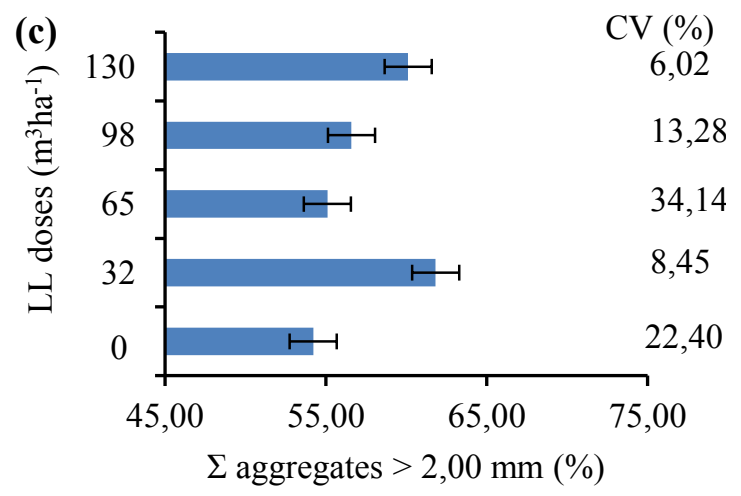

In relation to the indicators of soil porosity, the increase in diameter of the aggregates and the Ds has reduced the capacity of the total aeration of this layer in doses from $32 \mathrm{~m}^{3} \mathrm{ha}^{-1}$ season ${ }^{-1} \mathrm{LL}$, with a reduction of $0.0069 \mathrm{~m}^{3} \mathrm{~m}^{-3}$ to each cubic meter of LL applied (Figure 3c), as a consequence, there was an increase in the water retention capacity in balance with the tension $-6 \mathrm{kPa}$, equivalent to

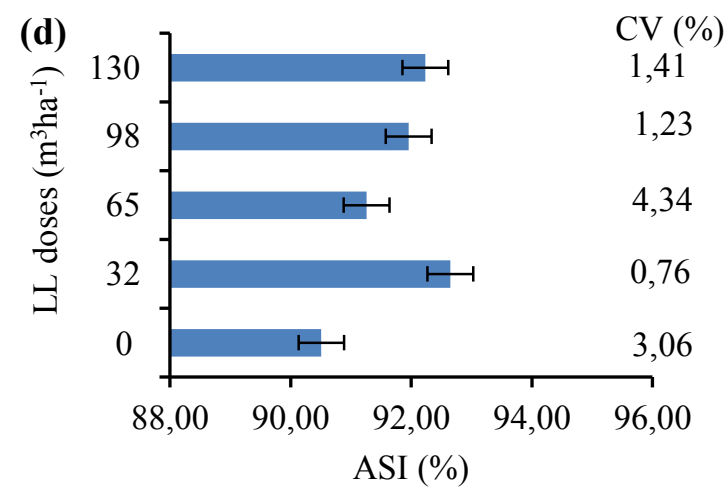

the field capacity (FC), in relation to the treatment without application of LL (Figure $3 \mathrm{e}$ ), with quadratic behavior and a point up of $0.37 \mathrm{~m}^{3} \mathrm{~m}^{-3}$ at a dose of 66 $\mathrm{m}^{3} \mathrm{ha}^{-1}$ season $^{-1}$. In addition, it was also observed a quadratic behavior of the ratio between macro and micro-pores in the superficial layer $(0.00-0.10 \mathrm{~m})$, with a minimum of $0.28 \mathrm{~m}^{3} \mathrm{~m}^{-3}$ at a dose of $98 \mathrm{~m}^{3}$ ha $^{-1}$ season $^{-1}$ (Figure 4a). 
Figure 2. Geometric mean diameter (GMD) and mean weight diameter (MWD) of layers 0.00-0.10 (a, c) and 0.10$0.20 \mathrm{~m}(\mathrm{~b}, \mathrm{~d})$ the ground after six years of applications of landfill leachate (LL) at doses $0,32,65,98$ and $130 \mathrm{~m}^{3} \mathrm{ha}^{-1}$ season $^{-1}$. The lines indicate the standard error of the difference between the averages and when they do not match they indicate that the difference is significant at $5 \%$ probability rate.

$$
0,00-0,10 \mathrm{~m}
$$
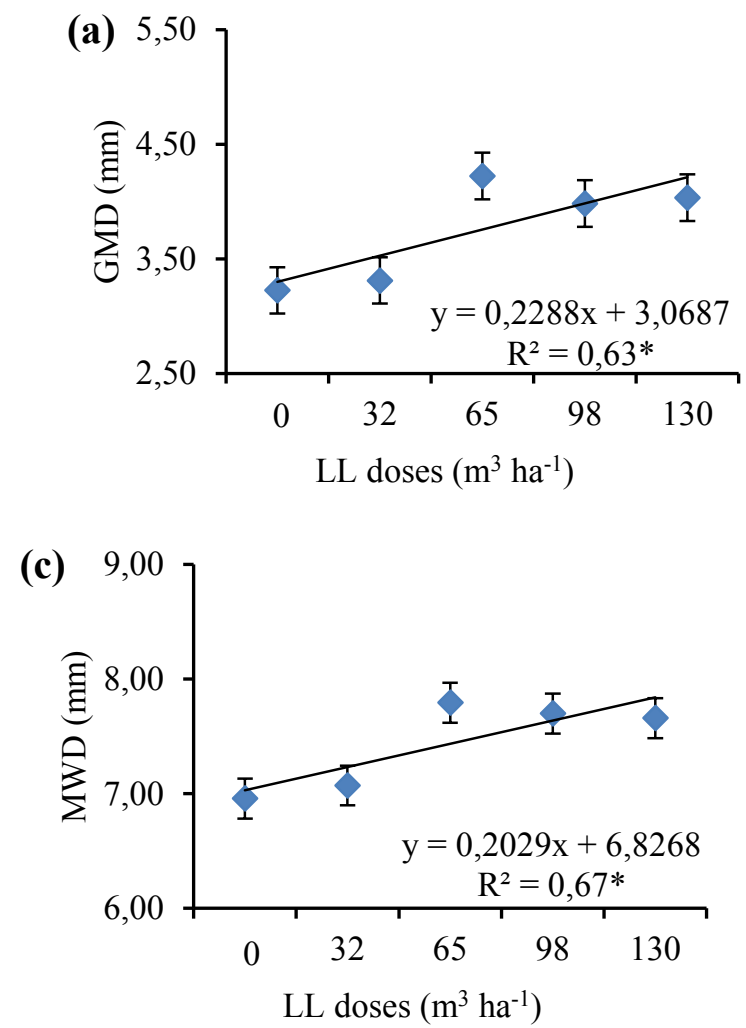

Depths
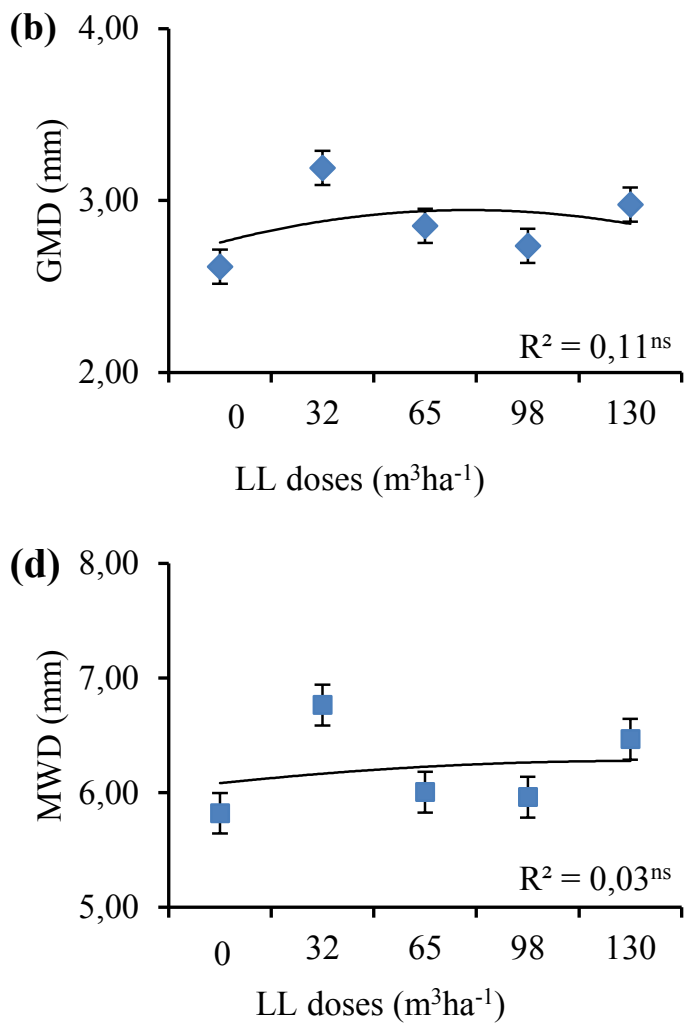

At doses of 65 and $98 \mathrm{~m}^{3} \mathrm{ha}^{-1}$ season $^{-1}$ of LL, the water content available was similar to the treatment without application (0), however the applications of 32 and $130 \mathrm{~m}^{3} \mathrm{ha}^{-1}$ season $^{-1}$ of LL reduced the availability of water for the plants at layer 0.00-0.10 $\mathrm{m}$ (Figure 5a). There was no correlation between the increasing doses of LL and the water content available $(\mathrm{R} 2=0.06, \mathrm{p}=0.58)$.

\section{Subsurface layer $(0.10-0.20 \mathrm{~m})$ of the soil}

In the subsurface layer $(0.10-0.20 \mathrm{~m})$ even though only the applications of 32 and $130 \mathrm{~m}^{3}$ $\mathrm{ha}^{-1}$ season $^{-1}$ result in increasing the proportion of households are larger than $2.00 \mathrm{~mm}$ (Figure 1c), the applications of 32, 65, 98 and $130 \mathrm{~m}^{3}$ ha $^{-1}$ season $^{-1}$ resulted in an increase in the ASI of this layer in relation to the treatment without application of LL (Figure 1d). The MWD and GMD were higher in treatments with LL, in relation to the treatment 0 , specially in applications of 32 and $130 \mathrm{~m}^{3} \mathrm{ha}^{-1}$ season $^{-1}$ (Figures $2 b$ and d). However, different from the surface layer (0.00-0.10 m), there was no direct relationship between the doses and the diameter of the aggregates. 
Figure 3. Soil bulk density (Ds), total aeration capacity (CAT) and field capacity (FC) of the layers $0.00-0.10$ (a, c, e) and $0.10-0.20 \mathrm{~m}(\mathrm{~b}, \mathrm{~d}, \mathrm{f})$ after six years of applications of landfill leachate (LL) at doses 0, 32, 65, 98 and $130 \mathrm{~m}^{3} \mathrm{ha}^{-1}$ season $^{-1}$. The lines indicate the standard error of the difference between the averages and when they do not match they indicate that the difference is significant at $5 \%$ probability rate. * Model significantly to $5 \%$.

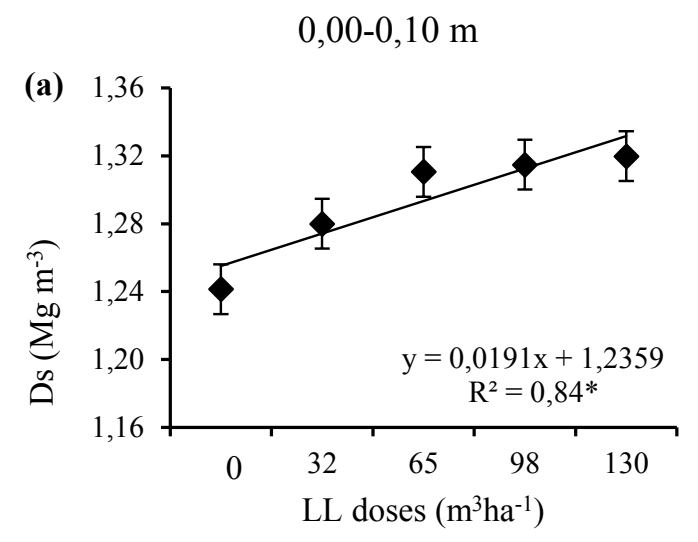

\section{Layers}
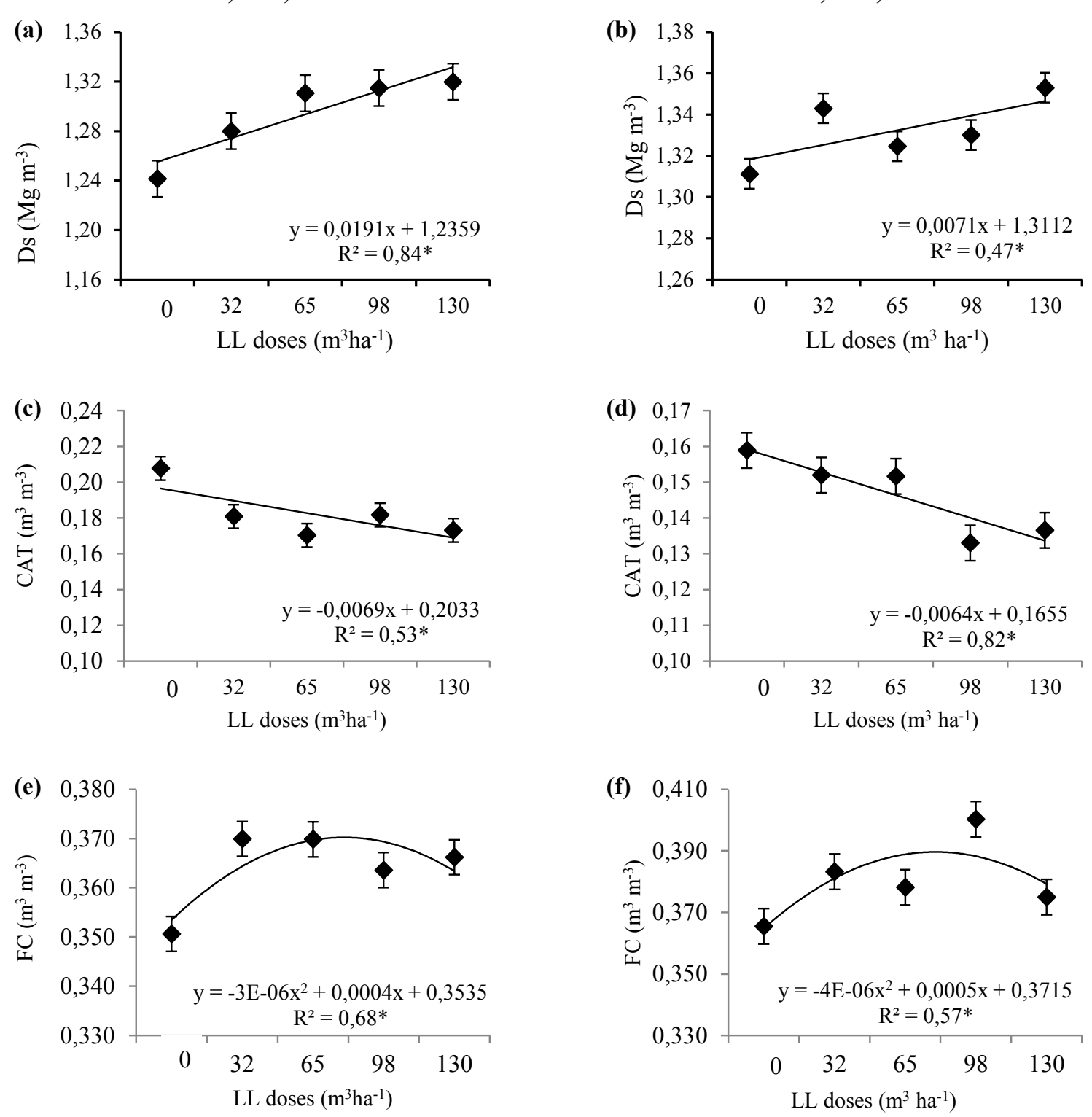

In a similar way to the aggregates, the soils that received doses of 32 and $130 \mathrm{~m}^{3}$ ha $^{-1}$ season $^{-1}$ showed higher Ds, however, the trend of increase of Ds with increasing doses of LL was less evident than in the superficial layer, with an increase of $0.0071 \mathrm{mg} \mathrm{m}^{-3}$ for each cubic meter of LL applied (Figure 3b).

In relation to the indicators of porosity at the layer 0.10 to $0.20 \mathrm{~m}$ there was also a linear trend of

reduction in the capacity of aeration of the soil (CAT) with the increase of the doses of LL, in the same proportion as in the surface layer, with reduction of $0.0064 \mathrm{~m} 3 \mathrm{~m}-3$ for each cubic meter of LL applied (Figure 3d), being significant starting from doses above $98 \mathrm{~m}^{3} \mathrm{ha}^{-1}$ season $^{-1}$, with a reduction of up to $15 \%$ of the total aeration capacity of the soil with applications of $130 \mathrm{~m}^{3}$ ha $^{-1}$ season $^{-1}$. 
Figure 4. Ratio between macro (Ma) and microporosity (Mi) of layers $0.00-0.10$ (a) and $0.10-0.20 \mathrm{~m}$ (b) of the soil after six years of applications of landfill leachate (LL) at doses 0, 32, 65, 98 and $130 \mathrm{~m}^{3} \mathrm{ha}^{-1}$ season $^{-1}$. * Significant Model to 5\%.

(a)

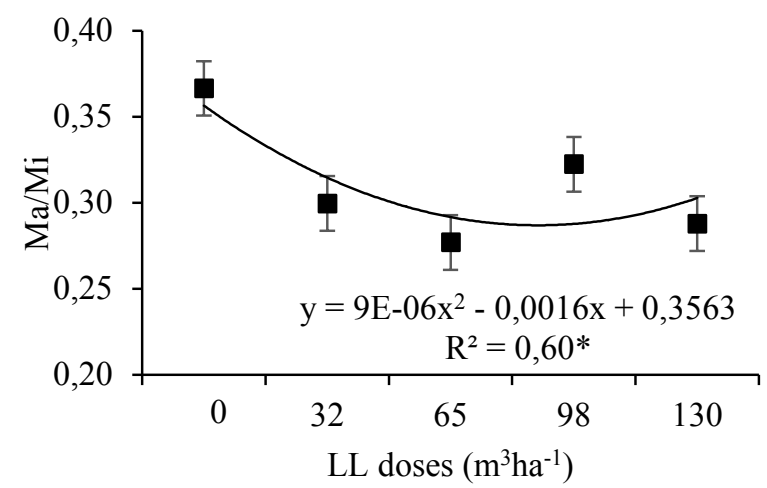

(b)

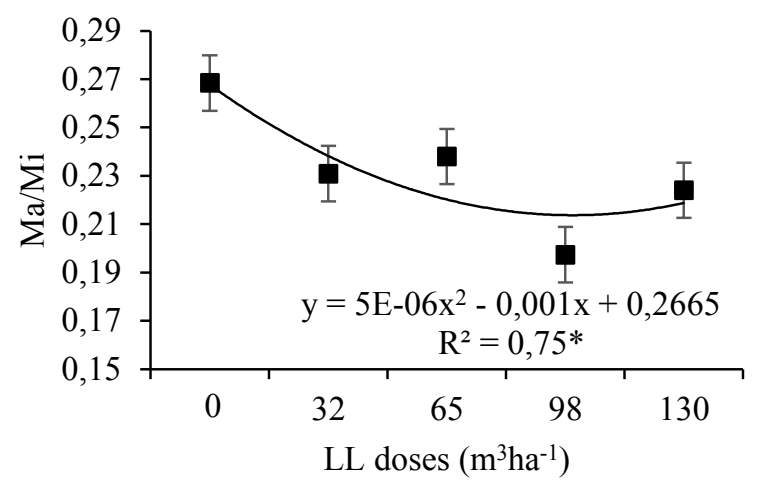

Figure 5. Water content available (AD) of the layers $0.00-0.10$ (a) and $0.10-0.20 \mathrm{~m}$ (b) of the soil after six years of application of landfill leachate (LL) at doses $0,32,65,98$ and $130 \mathrm{~m}^{3} \mathrm{ha}^{-1}$ season $^{-1}$. The lines indicate the standard error of the difference between the averages and when they do not match they indicate that the difference is significant at $5 \%$ probability rate.

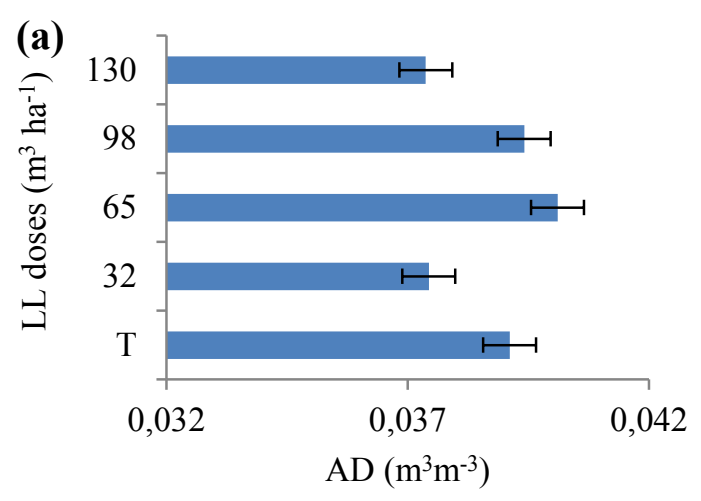

The applications of LL at doses of 32, 65, 98 and $130 \mathrm{~m}^{3} \mathrm{ha}^{-1}$ season $^{-1}$ promoted an increase in $\mathrm{FC}$ of layer 0.10 to $0.20 \mathrm{~m}$, in relation to the treatment 0 (Figure 3f), with a tendency in the quadratic relationship between FC and the doses of LL, with the maximum point at $0.38 \mathrm{~m}^{3} \mathrm{~m}^{-3}$ when applied $62 \mathrm{~m}^{3}$ ha $^{-1}$ season $^{-1}$. In addition, the relationship between the macro and microporosity decreased quadratically with increasing doses of LL (Figure 4b), with the minimum in 0.21 at a dose of $100 \mathrm{~m} 3$ ha- season-1.

In the subsurface layer $(0.10-0.20 \mathrm{~m})$, the applications from $32 \mathrm{~m}^{3} \mathrm{ha}^{-1}$ season $^{-1}$ LL have

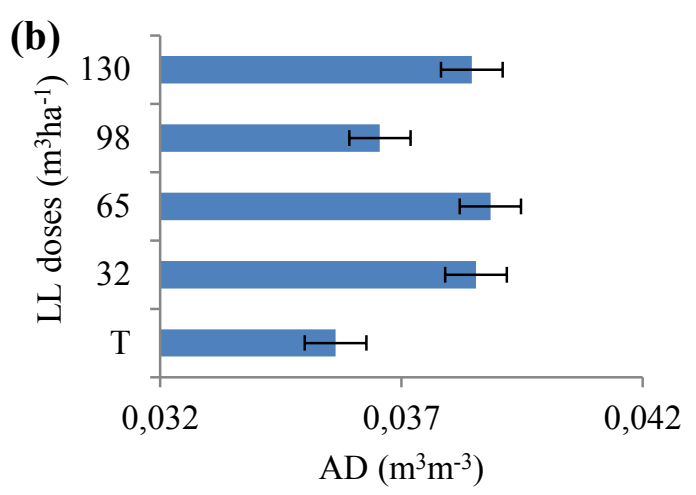

increased the availability of water for the plants, with the exception of the dose of $98 \mathrm{~m}^{3} \mathrm{ha}^{-1}$ season $^{-1}$, whose water content available was similar to the treatment without application of LL (Figure 5b).

Structure and porosity of the soil in relation to the carbon content

On the layer $0.00-00.10 \mathrm{~m}$, the contents of carbon in soil increased with the applications of doses from $32 \mathrm{~m}^{3} \mathrm{ha}^{-1}$ season ${ }^{-1}$, with quadratic behavior and increased levels up to the maximum point of $15.68 \mathrm{~g} \mathrm{~kg}^{-1}$ at a dose of $84 \mathrm{~m}^{3} \mathrm{ha}^{-1}$ season $^{-1}$ 
(Figure 6a). This increase of carbon with the In relation to the attributes of the porosity, it was applications of LL promoted a linear increase of Ds and the MWD and GMD of soil aggregates, with an increase of 0.3 and $0.4 \mathrm{~mm}$ of the MWD and GMD, observed that the carbon is related with the increase of FC and reducing the capacity of the total aeration and the ratio between macro and microporosity, with for each gram of carbon added by them (Figure 6b).

a reduction of $0.01 \mathrm{~m}^{3} \mathrm{~m}^{-3}$ of aeration porosity price of soil for each gram of carbon added by LL (Figure 6c).

Figure 6. The carbon content (a) and the relationship of this attribute with the attributes of aggregation (soil density, Ds and mean weight diameter MWD, and geometric mean diameter GMD of the aggregates) (b) and porosity (the ability to total aeration, CAT, field capacity, $\mathrm{CC}$, and the ratio between macro and microporosity, $\mathrm{Ma} / \mathrm{Mi}$ ) of the layer 0.00-0.10 m (c) after six years of applications of 0, 32, 65, 98 and $130 \mathrm{~m}^{3} \mathrm{ha}^{-1}$ season $^{-1}$ of landfill leachate (LL). The lines of the figure "a" and "b"indicate the standard error of the difference between the averages and when they do not match they indicate that the difference is significant at $5 \%$ probability rate.

Layer $0.00-0.10 \mathrm{~m}$

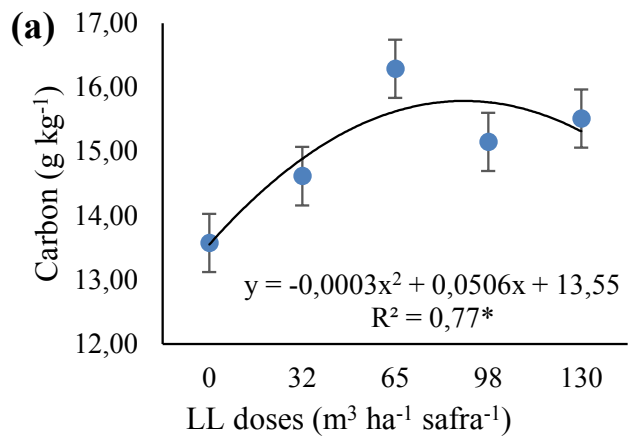

Layer $0.10-0.20 \mathrm{~m}$
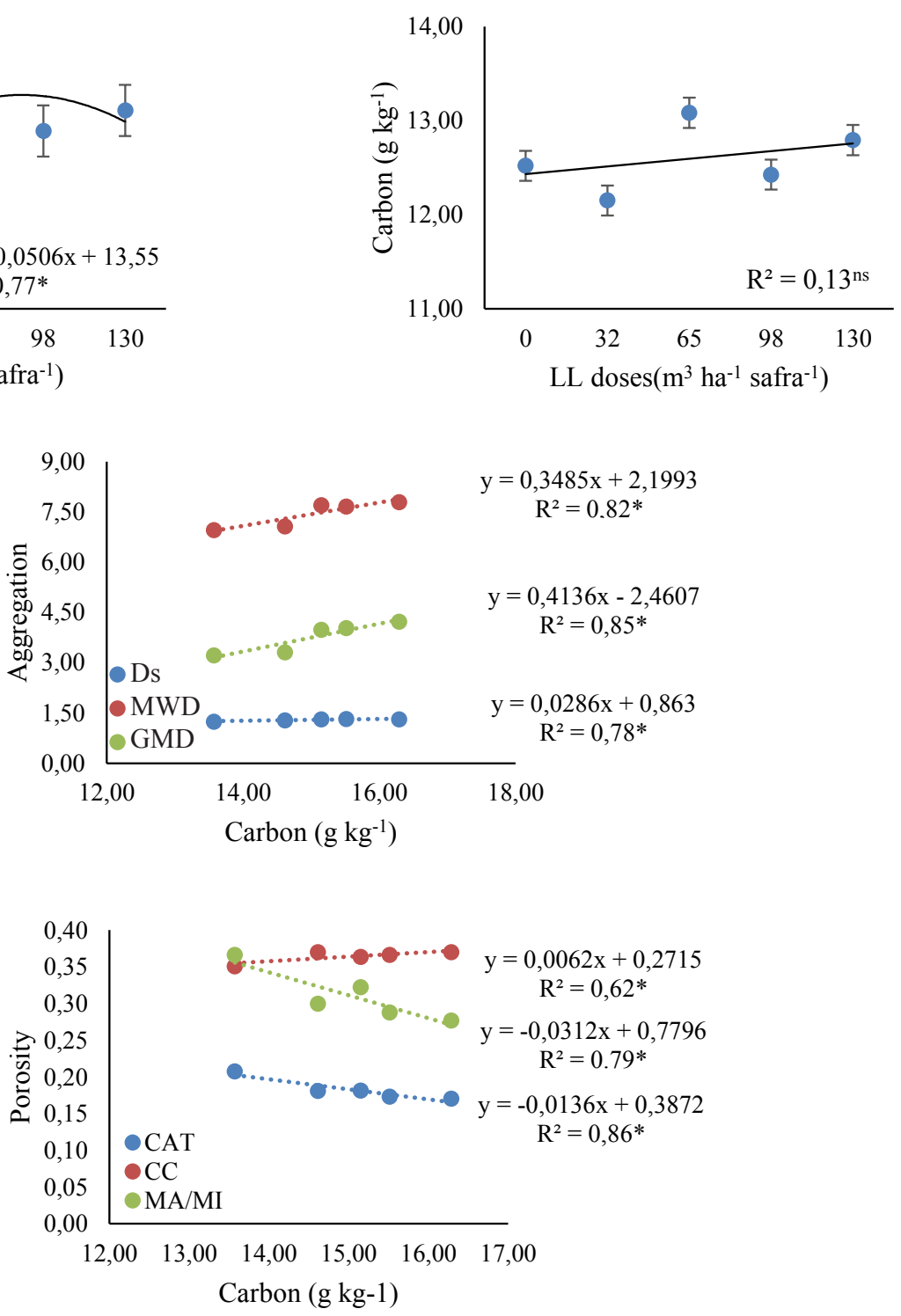

Ns not significant at $5 \%$ of probability rate

** Significant at $5 \%$ of probability rate. 


\section{Discussion}

Aggregation and porosity of the surface layer (0.00$0.10 \mathrm{~m}$ ) of the soil

The applications of LL in the soil, especially in doses from $65 \mathrm{~m}^{3} \mathrm{ha}^{-1}$ season $^{-1}$ promoted the increase of stability and of aggregates with a diameter greater than $2.00 \mathrm{~mm}$ (Figure 1a), the GMD and MWD of aggregates of this layer (Figure 2 A,c,e), and soil bulk density (Figure 3a), with consequent reduction of the $\mathrm{Ma} / \mathrm{MS}$ reason (Figure $4 \mathrm{a}$ ) and the CAT (Figure 3c).

These results indicate that initially the structural changes observed were caused by soil management, since, the cultures were exclusively made of successions of grasses (winter and summer).

The roots of these cultures work in the structuring of the soil by means of biophysical pressures (axial and radial), which promotes the approximation of mineral particles, favoring the soil aggregation (ZONTA et al., 2006).

According to Tisdall and Oades (1979) the grasses, associated with the release of polysaccharides by hyphae and mycorrhiza, are effective in increasing the stability of soil aggregates.

The use of increasing doses of LL resulted in the increase of soil organic carbon (Figure 6a), promoting the increase of the MWD and GMD, due to the increase of 0.35 and $0.41 \mathrm{~g} \mathrm{~kg}^{-1}$ of CO per mm of aggregate, Figure 6c.

However, there has been an increase of Ds with the addition of $0.02 \mathrm{~m}^{3} \mathrm{ha}^{-1}$ of LL by $\mathrm{Mg} \mathrm{m}^{-3}$ (Figure $3 a)$ reducing the $\mathrm{CAT}$, the $\mathrm{CC}$ (figure $3 \mathrm{c}, 3 \mathrm{e}$ ) and the ratio between macro and microporosity (Figure $4 \mathrm{a}$ ). These reductions can be explained by the effect of the roots of the grasses and organic carbon from the soil aggregation, as previously discussed. Another process explaining the increase of aggregation is the application of LL, near the seeding (3 days prior), during the five years of experiment. The application of this liquid residue resulted in an increase of soil moisture, in relation to the treatment without application, making the soil more susceptible to compression by machinery and agricultural implements used for seeding, which promoted the formation of aggregates and larger diameter.

The formation of this type of aggregate in the superficial layer is dependent on the intensity of compression that the soil is submitted (RICHART et al., 2005) and reduce the permeability of air and water (NUNES et al., 2014). Streck et al. (2004) show that no-tillage system with different passed to $10 \mathrm{Mg}$ subjected to moisture above the friable condition, resulted in an increase of Ds, reducing the total porosity and macroporosity, without an increase of the microporosity.

The field capacity has increased due to the reduction of reason $\mathrm{Ma} / \mathrm{MS}$, with the increase in the doses of LL (Figure 3e), the proportional increase of micropores resulted in a greater retention of water by the adsorption processes and capillarity. It is difficult to explain why the doses of 32 and $130 \mathrm{~m}^{3}$ ha $^{-1}$ season $^{-1}$ of LL specifically reduced the availability of water for the plants at layer $0.00-0.10$ $\mathrm{m}$ (Figure 5a) and more specific studies should be conducted to understand the relationship between the applications wand the availability of water, but for the dose of $\mathrm{m}^{3} \mathrm{ha}^{-1}$ season $^{-1}$ it may be related to a reduced amount of carbon contributed to the ground and to the dose of $130 \mathrm{~m}^{3} \mathrm{ha}^{-1}$ season $^{-1}$ at a greater intensity of alteration of the structures promoted by this dose of LL. It is important to emphasize that, as the application of the dose of $32 \mathrm{~m}^{3} \mathrm{ha}^{-1}$ season $^{-1}$ did not increase the Ds and reduced the capacity of aeration of the soil, since it addresses the superficial layer, the processes of humidification and desiccation of the aggregates can change the distribution of pores and consequently the availability of water for the plants.

With this, it is observed that the doses of up to $32 \mathrm{~m}^{3}$ ha $^{-1}$ season $^{-1}$ can be applied in the soil without negative influence on soil physical quality and can even stimulate the biological activity and improve the chemical fertility by the input of organic matter 
contained in the LL (BANDYOPADHYAY et al., 2010; BOLAN et al., 2013; SONG et al., 2013).

The physical quality of subperficial layer (0.10$0.20 \mathrm{~m}$ )

The effect of the applications of LL on the layer $0.10-0.20 \mathrm{~m}$ could be observed due to the liquid form, which allowed the infiltration of LL to this layer. In this layer, the lack of correlation with the organic carbon demonstrates the effect of soil management on the aggregates, especially by compression resulting from agricultural machinery traffic. The compression of the structure caused by the management was enhanced by applications of them, possibly for the same reasons as in the surface layer, i.e., by the stress distribution in the soil profile, showing an increasing trend of MWD and GMD and stability in water, in relation to the use of chemical fertilizer (Figures $1 b$ and 2b, d,f) and increase in Ds and a reduction in the capacity of aeration of the layer $0.10-0.20 \mathrm{~m}$ with increasing doses of LL (Figures 3b and d).

In the subsurface layer $(0.10-0.20 \mathrm{~m})$, the applications of doses from $32 \mathrm{~m}^{3} \mathrm{ha}^{-1}$ season $^{-1}$ of LL have increased the availability of water for the plants, with the exception of the dose of $98 \mathrm{~m}^{3} \mathrm{ha}^{-1}$ season $^{-1}$, whose water content available was similar to the treatment with mineral fertilizer (0) (Figure $5 b)$.

In the subsurface layer $(0.10-0.20 \mathrm{~m})$, the increase of water available can be explained, in part, by the increase of Ds and the field capacity (FC) and by the correlation of the $\mathrm{AD}$ with the content of soil organic carbon (CO) (Table 3 ). The association of increased FC and the relationship with organic carbon content suggests that the applications of LL increase the water retention capacity of the soil by the processes of capillarity (for the field capacity) and adsorption (by comparison with the organic carbon), and that this increase in water content is available to the plants.
It is noteworthy that the compression and reduced ability to aeration of $0.00-0$ layer $0.10 \mathrm{~m}$ with the applications of LL may have less effect on the erosion whereas this layer the porosity can be altered by the stalk of the planter and the cycles of wetting and drying of the soil, as mentioned earlier. However in the subsurface layer $(0.10-0.20 \mathrm{~m})$ the increase of households and the Ds and the reduction of porosity and ability of aeration may be more problematic, whereas this layer is less prone to cycles of wetting and drying of the aggregates and the lighting trencher from drill.

\section{Conclusions}

Considering the physical quality of the soil, the controlled application of landfill leachate in agricultural soils in doses of $32 \mathrm{~m} 3$ ha-1 is an alternative to the final disposal of this waste, because it did not promote an increase of the aggregates larger than $2 \mathrm{~mm}$ in the superficial layer $(0.00-0.10$ $\mathrm{m}$ ) and was the dose with less influence on reducing the aeration of the soil, in relation to the applications of 65,98 and $130 \mathrm{~m}^{3} \mathrm{ha}^{-1}$ in the layers $0.00-00.10$ and $0.10-0.20 \mathrm{~m}$.

The doses from 65 up to $130 \mathrm{~m}^{3} \mathrm{ha}^{-1} \mathrm{crop}^{-1}$ promoted an increase in households with a diameter greater than $2.00 \mathrm{~mm}$ and the density of the soil, with a consequent reduction in the ratio between macro and micro-pores and the capacity of aeration of the soil in layers $0.00-00.10$ and $0.10-0.20 \mathrm{~m}$.

\section{Acknowledgments}

Our thanks to CNPQ for granting a research scholarship to the last author.

\section{References}

AGOSTINI, P.; CARLON, C.; CRITTO, A.; MARCOMINI, A. A step toward contaminated megasites management: six European experiences at comparison. In: VELINNI, A. A. Landfill research trends. New York: Nova Science Publishers, 2007. cap. 2, p. 47-73. 
ALVAREZ, C. L.; STAPE, J. L.; SENTELHAS, P. C.; GONÇALVES, J. L. M.; SPAROVEK, G. Köppen's climate classification map for Brasil. Meteorologische Zeitschrift, Stuttgart, v. 22, n. 6, p. 711-728, 2013.

ASSOCIAÇÃO BRASILEIRA DE NORMAS TÉCNICAS - ABNT. NBR 8419: Apresentação de projetos de aterros sanitários de resíduos sólidos urbanos: procedimento. Rio de Janeiro: ABNT, 1992. Disponível em: <http://sites.unicentro.br/wp/educacaoambiental/ files/2017/04/NBR-8419.pdf>. Acesso em: 27 jul. 2017.

BANDYOPADHYAY, K. K.; MISRA, A. K.; GHOSHPK, P. K.; HATI, K. M. Effect of integrated use of farmyard manure and chemical fertilizers on soil physical properties and productivity of soybean. Soil and Tillage Research, Amsterdam, v. 110, n. 1, p. 115-125, 2010.

BARBOSA, G. M. C.; OLIVEIRA, J. F.; MIYAZAWA, M.; RUIZ, D. B.; TAVARES FILHO, J. Aggregation and Clay dispersion of an Oxisol treated with swine and poultry manures. Soil and Tillage Research, Amsterdam, v. 146, part. B, p. 279-285, 2015.

BOLAN, N. S.; KUNHIKRISHNAN, A.; NAIDU, R. Carbon storage in a heavy clay soil landfill site after biosolid application. Science of The Total Environment, Wisconsin-Madison, v. 465, n. 3, p. 216-225, 2013.

CASTRO FILHO, C.; MUZILLI, O.; PODANOSCHI, A. Estabilidade dos agregados e sua relação com o teor de carbono orgânico num Latossolo Roxo distrófico, em função de sistemas de plantio, rotações de culturas e métodos de preparo das amostras. Revista Brasileira de Ciência de Solo, Campinas, v. 22, n. 3, p. 527-538, 1998.

CHERUBIN, M. R.; EITELWEIN, M. T.; FABBRIS, C.; WEIRICH, S. W.; SILVA, R. F.; SILVA, V. R.; BASSO, C. J. Qualidade física, química e biológica de um Latossolo com diferentes manejos e fertilizantes. Revista Brasileira de Ciência de Solo, Viçosa, MG, v. 39, n. 2, p. 615-625, 2015.

COELHO, D. C. L.; BATISTA, R. O.; MESQUITA, F. O.; SILVA, K. B. da; ALVES, S. M. C.; GURGEL, M. T. Trace elements in Ultisol irrigated with landfill leachate and public-supply water. Revista Brasileira de Engenharia Agrícola e Ambiental, Campina Grande, v. 20, n. 8, p. 769-774, 2016.

DANE, J. H.; HOPMANS, J. W. Hanging water column. In: DANE, J. H.; TOPP, G. C. (Ed.). Methods of soil analysis: physical methods. Madison: Soil Science Society of America, 2002. p. 680-683.

DONAGEMA, G. K.; CAMPOS, D. V. B. de; CALDERANO, S. B.; TEIXEIRA, W. G.; VIANA, J. H. M. (Org.). Manual de métodos de análise do solo.
2. ed. rev. Rio de Janeiro: Embrapa Solos, 2011. 230 p. (Embrapa Solos. Documentos, 132).

GALKO, G. The influence of infiltration of leachate from landfills on the changes of chemical parameters of the soil. Journal of Ecological Engineering, Nadbystrzycka, v. 16, n. 4, p. 198-205, 2015.

HAARSTAD, K.; HENSEL, G.; PARUCH, A. M.; BLANKENBERG, A. G. B. Phosphorus recycling from waste, dams and wetlands receiving landfill leachate - long term monitoring in norway. In: VYMAZAL, J. (Ed.). Natural and constructed wetlands. London: Springer, 2016. p. 141-146.

HOORNWEG, D.; BHADA-TATA, P. What a waste: a global review of solid waste management. $15^{\text {th }}$ ed. Washington: World Bank, 2012.98 p.

KLUTE, A. Water retention: laboratory methods. In: (Ed.). Methods of soil analysis: physical and mineralogical methods. Madison: American Soil Society of Agronomy, 1986. p. 635-660.

KUWANO, B. H.; NOGUEIRA, M. A.; SANTOS, C. A.; FAGOTTI, D. S. L.; SANTOS, M. B., LESCANO, L. E. A. M.; DIVA, S. A.; BARBOSA, G. M. C.; TAVARESFILHO, J. Application of landfill leachate improves wheat nutrition and yield but has minor effects on soil properties. Journal of Environmental Quality, Madison, v. 46, n. 1, p. 153-159, 2017.

MANGIERI, V. R. L.; TAVARES FILHO, J. Disposição de resíduos sólidos no solo: efeito nos atributos físicos, químicos e na matéria orgânica. Semina: Ciências Agrárias, Londrina, v. 36, n. 2, p. 747-764, 2015.

MARTINS, C. L.; CASTILHOS JÚNIOR, A. B.; COSTA, R. H. R. Desempenho de sistema de tratamento de lixiviado de aterro sanitário com recirculação do efluente. Revista Brasileira Engenharia Agrícola Ambiental, Campina Grande, v. 15, n. 4, p. 401-410, 2010 .

MAZURANA, M.; LEVIEN, R.; MULLER, J.; CONTE, O. Sistemas de preparo de solo: alterações na estrutura do solo e rendimento das culturas. Revista Brasileira de Ciência de Solo, Viçosa, MG, v. 35, n. 4, p. 1197-1206, 2011.

MORAES, M. T.; DEBIASI, H.; CARLESSO, R.; FRANCHINI, J. C.; SILVA, V. R. da; LUZ, F. B. da. Soil physical quality on tillage and cropping systems after two decades in the subtropical region of Brazil. Soil and Tillage Research, Amsterdam, v. 155, n. 1, p. 351-362, 2016. 
NUNES, M. R.; PAULETTO, E. A.; DENARDIN, J. E.; FAGANELLO, A.; SPINELLI PINTO, L. F.; SCHEUNEMANN, T. Persistência dos efeitos da escarificação sobre a compactação de Nitossolo sob plantio direto em região subtropical úmida. Pesquisa Agropecuária Brasileira, Brasília, v. 49, n. 7, p. 531-539, 2014.

OLIVEIRA, D. M. S.; LIMA, R. P. de; VERBURG, E. E. J. Qualidade física do solo sob diferentes sistemas de manejo e aplicação de dejeto líquido suíno. Revista Brasileira Engenharia Agrícola Ambiental, Campina Grande, v. 19, n. 3, p. 280-285, 2015.

PANCHONI, L. C.; SANTOS, C. A.; KUWANO, B. H.; CARMO, K. B.; CELY, M. V. T.; OLIVEIRA-JÚNIOR, A. G.; FAGOTTI, D. S. L.; CERVANTES, V. N. M.; ZANGARO, W.; ANDRADE, D. S.; ANDRADE, G.; NOGUEIRA, M. A. Effect of Landfill leachate on cereal nutrition and productivity and on soil properties. Journal of Environmental Quality, Madison, v. 45, n. 3, p. 10801086, 2016.

REIS, M. F.; CONTI, D.; CORRÊA, R. M. Gestão de resíduos sólidos: desafios e oportunidades para a cidade de São Paulo. RISUS - Journal on Innovation and Sustainability, São Paulo, v. 6, n. 3, p. 77-96, 2015.

RICHART, A.; TAVARES FILHO, J.; BRITO, O. R.; LLANILLO, R. F.; FERREIRA, R. Compactação do solo: causas e efeitos. Semina: Ciências Agrárias, Londrina, v. 26, n. 3, p. 321-344, 2005.

RONG, L.; ZHANG, C.; JIN, D.; DAI, Z. Assessment of the potential utilization of municipal solid waste from a closed irregular landfill. Journal of Cleaner Production, Oxford, v. 142, Part 1, p. 413-419, 2017.

SALAM, M. M. A.; KAIPIAINEN, E.; MUHAMMAD, M.; VILLA, A.; KUITTINEN, S.; PULKKINEN, P.; PELKONEN, P.; MEHTÄTALO, L.; PAPPINEN, A. Effects of contaminated soil on the growth performance of young Salix (Salix schwerinii E. L. Wolf) and the potential for phytoremediation of heavy metals. Journal of Environmental Management, Oxford, v. 183, n. 1, p. 1-11, 2016.
SANTOS, C. A.; PANCHONI, L. C.; BINI, D.; KUWANO, B. H.; CARMO, K. B.; SILVA, S. M. C. P.; MARTINES, A. M.; ANDRADE, G.; ANDRADE, D. S.; CARDOSO, E. J. B. N.; ZANGARO, W.; NOGUEIRA, M. A. Land application of municipal landfill leachate: fate of ions and ammonia volatilization. Journal of Environmental Quality, Madison, v. 42, n. 2, p. 523-531, 2013.

SILVA, H.; BARBIERI, A. F.; MONTE-MÓR, R. L. Demografia do consumo urbano: um estudo sobre a geração de resíduos sólidos domiciliares no município de Belo Horizonte. Revista Brasileira de Estudos de População, Belo Horizonte, v. 29, n. 2, p. 421-449, 2012.

SONG, U.; WALDMAN, B.; LEE, E. J. Ameliorating topsoil conditions by biosolid application for a waste landfill landscape. International Journal of Environmental Research, Winter, v. 7, n. 1, p. 1-10, 2013.

STRECK, C. A.; REINERT, D. J.; REICHERT, J. M.; KAISER, D. R. Soil physical alterations with soil compaction induced by traffic of a tractor in no-tillage system. Ciência Rural, Santa Maria, v. 34, n. 3, p. $755-$ 760, 2004.

TISDALL, J. M.; OADES, J. M. Stabilization of soil aggregates by the root system of ryegrass. Australian Journal Soil Research, Alexandria, v. 17, n. 1, p. 429441, 1979.

YODER, R. E. A direct method of aggregate analysis of soils and a study of the physical nature of erosion losses. Journal American Society Agronomy, Madison, v. 28, n. 5, p. 337-351, 1936.

ZONTA, E.; BRASIL, F.; GOI, S. R.; ROSA, M. M. T. $\mathrm{O}$ sistema radicular e suas interações com o ambiente edáfico. In: FERNANDES, M. S. (Ed.). Nutrição mineral de plantas. Viçosa, MG: Sociedade Brasileira de Ciência do Solo, 2006. p. 7-52. 